\title{
Pengaruh Variasi Panjang Serat Ampas Tebu dan Serbuk Kulit Buah Kakao Terhadap Sifat Fisis, Mekanis, dan Konduktivitas Termal Papan Partikel
}

\author{
Rahmi Suryani $^{1, *}$, Muldarisnur $^{1}$, Yuli Yetri ${ }^{2, * * *}$ \\ ${ }^{1}$ Jurusan Fisika FMIPA Universitas Andalas, Padang, Indonesia \\ ${ }^{2}$ Jurusan Teknik Mesin, Politeknik Negeri Padang, Padang, Indonesia \\ *aamilea12@gmail.com \\ **yuliyetri@pnp.ac.id
}

\begin{abstract}
ABSTRAK
Penelitian ini bertujuan untuk memanfaatkan limbah ampas tebu dan kulit kakao untuk pembuatan papan partikel dengan memvariasikan panjang serat tebu 1 sampai $5 \mathrm{~cm}$ dan serbuk kulit kakao yang lolos ayakan 60 mesh dengan perbandingan massa 50:50 menggunakan perekat isosianat sebanyak $16 \%$ dari massa sampel. Pengujian yang dilakukan yaitu uji fisis berupa densitas, kadar air, dan daya serap air. Uji mekanis berupa kuat lentur dan kuat patah serta uji konduktivitas termal. Hasil pengujian didapatkan nilai densitas berkisaran antara $0,95-1,3 \mathrm{~g} / \mathrm{cm}^{3}$, nilai kadar air $0,100-0,135 \%$ dan nilai daya serap air 0,205 $0,605 \%$. Nilai kuat lentur berkisaran $6270-10800 \mathrm{~kg} / \mathrm{cm}^{2}$, nilai kuat patah $17800-27500 \mathrm{~kg} / \mathrm{cm}^{2}$, nilai konduktivitas termal berkisaran $0,00701-0,00924 \mathrm{~W} / \mathrm{m}^{\circ} \mathrm{C}$. Dari hasil dapat disimpulkan bahwa panjang serat ampas tebu mempengaruhi nilai uji fisis, mekanis, dan konduktivitas termal papan partikel. Papan partikel yang dihasilkan sudah memenuhi SNI 03-2105-2006, namun pada pengujian mekanis uji kuat lentur nilai yang dihasilkan belum memenuhi standar dan nilai densitas papan yang didapatkan lebih tinggi dari standar.

Kata kunci: serbuk kakao, papan partikel, konduktivitas termal.
\end{abstract}

\section{ABSTRACT}

This study aims to utilize bagasse and cocoa peel waste for the manufacture of particle boards by varying the length of sugarcane fiber 1 to $5 \mathrm{~cm}$ by mixing cocoa skin powder that passes the 60 mesh sieve with a mass ratio of 50:50 and using isocyanate adhesive as much as $16 \%$ of the sample mass. Tests carried out are physical tests in the form of density, water content, and water absorption. The tests are done after the sample is 7 days old.The results of the test is density values ranging between $0.95-1.3 \mathrm{~g} / \mathrm{cm}^{3}$, the value of water conten are $0.100-0.135 \%$ and the value of water absorption are $0.205-0.605 \%$. The value of flexural strength ranges from $6270-10800 \mathrm{~kg} / \mathrm{cm}^{2}$, the value of fracture is $17800-27500 \mathrm{~kg} / \mathrm{cm}^{2}$, the value of thermal conductivity ranges from $0.00701-0.00924 \mathrm{~W} / \mathrm{m}^{\circ} \mathrm{C}$.Mechanical tests are flexural strength and fracture strength and thermal conductivity test. The test results concluded that the length of bagasse fiber affects the physical, mechanical, and thermal conductivity values of the particle board. The particle board produced meets SNI 03-2105-2006, but in mechanical testing the flexural strength of the resulting value does not meet the standards and the board density value obtained is higher than the standard.

Keywords: cocoa powder, particle board, thermal conductivity

\section{PENDAHULUAN}

Peningkatan jumlah penduduk, industrialisasi, dan gaya hidup berdampak pada peningkatan kebutuhan seperti kebutuhan dasar energi, sandang, papan, dan pangan. Pemenuhan kebutuhan papan untuk perumahan dan furniture sangat bergantung pada ketersediaan kayu. Produktivitas hutan yang semakin menurun akan berakibat pada kesulitan untuk memenuhi kebutuhan bahan baku kayu. Papan partikel merupakan produk komposit atau panel kayu yang terbuat dari partikel-partikel kayu dan bahan-bahan berlignoselulosa lainnya, yang diikat dengan perekat atau bahan pengikat lain dan kemudian dikempa panas (Maloney, 1993). Papan partikel dapat dibuat dengan menggunakan bahan buangan seperti, serbuk gergaji, sekam padi, ampas tebu dan cangkang kulit buah kakao. Pembuatan papan partikel dengan mengolah bahan buangan dapat mengurangi limbah dan memberikan nilai tambah.

Tebu merupakan salah satu komoditi perkebunan yang mengandung unsur lignoselulosa sehingga dapat dijadikan bahan baku dalam pembuatan papan partikel. Menurut Iswanto (2007), selama ini pemanfaatan tebu hanya digunakan pada industri pengelolahan gula, sedangkan ampas tebu sekitar $35-40 \%$ dari berat tebu hanya dimanfaatkan sebagai bahan bakar 
industri dan dibuang sebagai limbah. Serat ampas tebu mengandung silika $62,78 \%$, yang merupakan bahan keramik isolator.

Serat ampas tebu memiliki kekuatan dan daya rekat yang kurang baik, hal ini dapat diatasi dengan mencampurkan bahan lain seperti limbah kulit buah kakao (Krisna, 2009). Kulit buah kakao mengandung 60\% lignoselulla yang bisa dimanfaakan sebagai bahan perekat alternatif (Ashadi, 2005). Kakao memiliki banyak kelebihan, selain murah buah kakao banyak diproduksi di daerah Sumatera Barat khususnya di daerah Air Dingin Kecamatan Koto Tangah Kota Padang. Pemanfaatan limbah kulit buah kakao selama ini digunakan untuk makanan ternak sapi, pemanfaatan tersebut belum optimal dilakukan. Pemanfaatan kulit buah kakao sebagai papan partikel diharapkan dapat mengatasi permasalahan limbah kulit buah kakao yang terus meningkat.

Najihah dkk (2018) telah melakukan pengujian sifat fisis dan sifat mekanis papan partikel dari campuran ampas tebu dan serbuk kulit buah kakao dan membandingkannya dengan Standar Nasional Indonesia (SNI) No. 03-2105-2006. Papan partikel yang terbaik adalah papan partikel dangan perbandingan komposisi kulit buah kakao dan ampas tebu 50:50, dengan kadar perekat isosianat $16 \%$ dari massa sampel yang digunakan, namun pada penelitian ini tidak melakukan pengujian konduktivitas termal.Maiwita dkk (2014) melakukan penelitian sifat konduktivitas termal menggunakan campuran ampas tebu dan serbuk gergaji diperoleh nilai konduktivitas termal terkecil terdapat pada perbandingan komposisi ampas tebu dan serbuk gergaji yaitu 100:0 dengan nilai konduktivitas termal $0,08 \mathrm{~W} / \mathrm{m}^{\circ} \mathrm{C}$, sedangkan konduktivitas termal terbesar dengan perbandingan ampas tebu dan serbuk gergaji 50:50 dengan nilai konduktivitas termal $0,14 \mathrm{~W} / \mathrm{m}^{\circ} \mathrm{C}$. Berdasarkan penelitian sebelumnya, maka dilakukan penelitian tentang pengaruh panjang serat ampas tebu dengan campuran serbuk kakao terhadap sifat fisis, mekanis, dan konduktivitas termal papan partikel.

\section{METODE}

Bahan yang digunakan pada penelitian ini adalah serat ampas tebu hasil dari limbah pedagang es tebu yang berjualan disekitar tepi pantai Muaro Padang. Kemudian ampas tebu direndam selama 2 jam untuk menghilangkan kadar gula yang terkandung pada ampas tebu. Setelah direndam, dilakukan pengeringan selama 7 hari diruangan yang tidak terkena sinar matahari secara langsung. Setelah kering dilakukan pemisahan serat pada ampas tebu, lalu dipotong dengan variasi panjang serat yaitu $1 \mathrm{~cm}, 2 \mathrm{~cm}, 3 \mathrm{~cm}, 4 \mathrm{~cm}$ dan $5 \mathrm{~cm}$. Buah kakao diperoleh di daerah Air Dingin Kecamatan Koto Tangah Kota Padang. Buah kakao dikeluarkan isinya lalu cangkang buah kakao tersebut diiris tipis, setelah itu dilakukan pengeringan selama 7 hari hingga kulit kakao tersebut kering. Setelah kering, kulit buah kakao tersebut digiling menggunakan ballmill hingga membentuk serbuk. Kemudian serbuk kulit buah kakao diayak menggunakan ayakan dengan ukuran 60 mesh $(250 \mu \mathrm{m})$. Papan partikel dibuat dengan ukuran $12 \mathrm{~cm}$ x $8 \mathrm{~cm} \times 1 \mathrm{~cm}$ dengan total massa bahan 54 gram. Komposisi ampas tebu dan serbuk kakao yaitu 50:50 serta penambahan perekat isosianat sebanyak 16\% dari massa sampel.

Tahapan pembuatan sampel yaitu semua bahan ditimbang dengan komposisi yang telah dihitung lalu dicampurkan ke dalam satu wadah lalu diaduk, campuran bahan kemudian dituangkan ke dalam cetakan plat aluminium yang berukuran $12 \mathrm{~cm}$ x $18 \mathrm{~cm}$ x $1 \mathrm{~cm}$. Kemudian dilakukan pengempaan selama 6 menit sehingga terbentuk lembaran papan dengan ketebalan kurang dari $1 \mathrm{~cm}$, lalu dilakukan pengondisian dengan suhu ruangan selama 7 hari sebelum dilakukan pengujian. Pengujian papan partikel yang dilakukan yaitu uji sifat fisis, sifat mekanis berdasarkan Standar SNI 03-2105-2006, serta pengujian konduktivitas termal papan.

\section{HASIL DAN DISKUSI}

\subsection{Densitas}

Nilai densitas diperoleh dari pengukuran massa dan volume dari papan partikel.Setelah dilakukan pengukuran massa dan volume selanjutnya nilai kerapatan dapat dihitung. Muharam (1995) menyatakan bahwa faktor penting yang mempengaruhi nilai densitas papan partikel adalah kerapatan, bahan baku yang dipakai dankepadatan lembaran. Nilai kerapatan papan partikel tertinggi diperoleh pada variasi panjang serat tebu $5 \mathrm{~cm}$ yaitu sebesar $1,3 \mathrm{~g} / \mathrm{cm}^{3}$ dan 
nilai kerapatan terendah pada variasi panjang serat tebu $1 \mathrm{~cm}$ yaitu sebesar $1,11 \mathrm{~g} / \mathrm{cm}^{3}$.Standar SNI 03-2105-2006 mensyaratkan bahwa kerapatan papan partikel yaitu 0,5 - 0,9 g/ $\mathrm{cm}^{3}$, maka nilai kerapatan yang diperoleh pada penelitian ini dengan semua variasi panjang serat tebu yang digunakan lebih tinggi dari standar mutu yang telah ditetapkan. Pengaruh variasi panjang serat terhadap nilai densitas dapat dilihat pada Gambar 1.

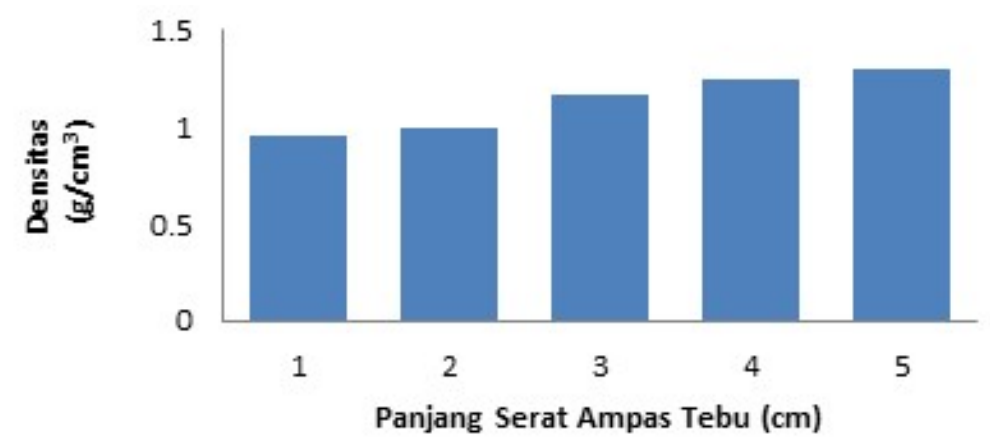

Gambar 1 Pengaruh panjang serat terhadap densitas papan partikel

\subsection{Kadar Air}

Nilai kadar air tertinggi didapatkan pada variasi serat tebu dengan panjang $1 \mathrm{~cm}$ yaitu $0,135 \%$ dan nilai kadar air terendah pada variasi panjang serat tebu $5 \mathrm{~cm}$ yaitu $0,100 \%$. Hal ini memperlihatkan nilai kadar air menurun dengan semakin panjangnya serat tebu yang digunakan.Kadar air papan partikel bergantung pada kondisi udara disekitarnya, karena papan partikel terdiri atas bahan yang mengandung lignoselulosa menyebabkan papan bersifat higroskopis dan lembab (Iswanto,2008). Ruhendi dkk (2007) menyatakan bahwa kadar air papan partikel dipengaruhi oleh nilai densitasnya, papan dengan densitas tinggi memiliki ikatan antar molekul sangat kuat sehingga molekul air sulit mengisi rongga dalam papan partikel. Berdasarkan Standar SNI 03-2105-2006 nilai kadar air papan partikel ditetapkan tidak melebihi $14 \%$. Dengan demikian semua nilai dari papan partikel menggunakan variasi panjang serat tebu pada penelitian ini memenuhi standar papan partikel. Pengaruh variasi panjang serat terhadap nilai kadar air dapat dilihat pada Gambar 2.

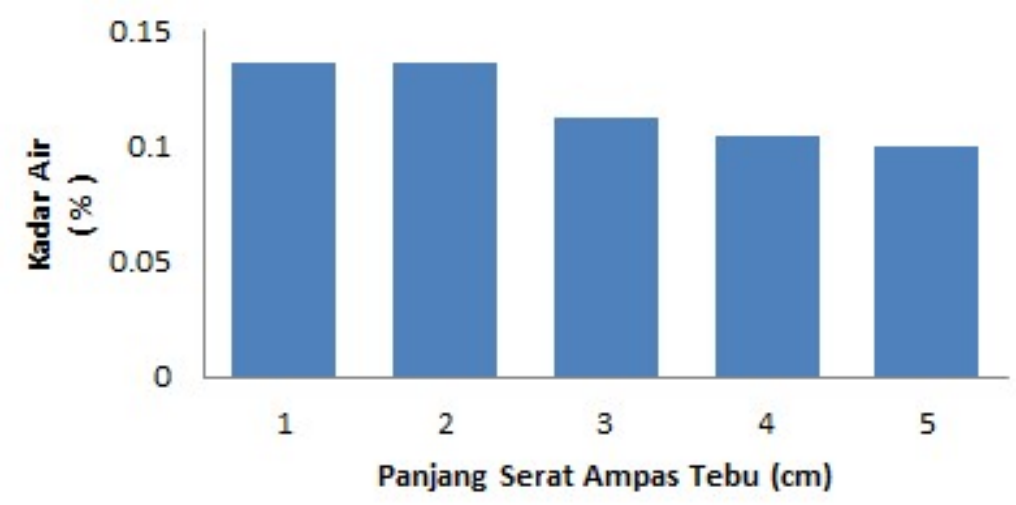

Gambar 2 Pengaruh panjang serat terhadap kadar air papan partikel

\subsection{Daya Serap Air}

Daya serap air papan partikel memperlihatkan bagaimana kemampuan dari papan partikel untuk menyerap air selama 24 jam perendaman.Daya serap air papan semakin menurun dengan semakin panjang variasi serat yang digunakan yaitu pada variasi panjang $5 \mathrm{~cm}$. Nilai daya serap air berbanding terbalik dengan nilai kerapatan papan, semakin tinggi nilai kerapatan papan maka semakin kecil daya serap air pada papan.Malau dkk (2015) menyatakan semakin tinggi densitas papan partikel, maka ikatan antar partikel akan semakin kompak dan menyebabkan rongga udara semakin kecil, sehingga air menjadi sulit untuk mengisi rongga, akibatnya daya serap air papan partikel akan semakin rendah.Berdasarkan Standar SNI 03-2105- 
2006 tidak menjelaskan tentang standar nilai daya serap air. Pengaruh panjang serat terhadap nilai daya serap air dapat dilihat pada Gambar 3.

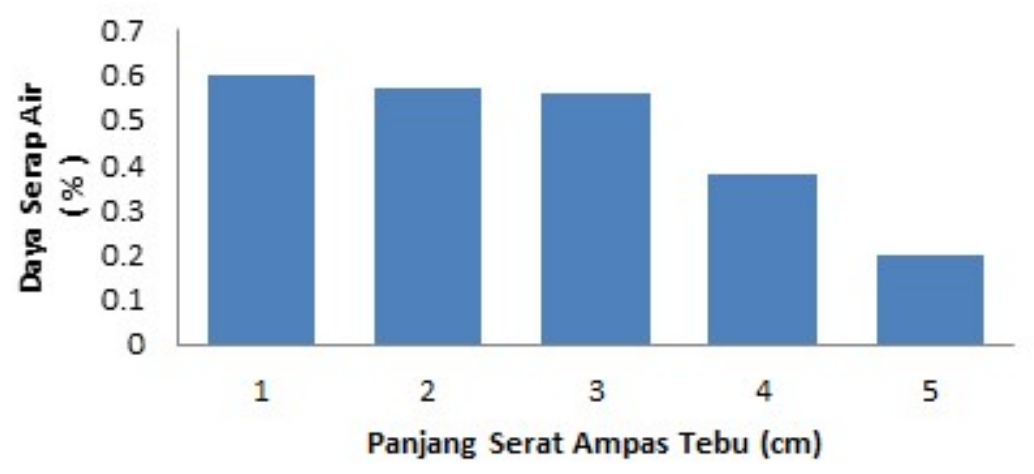

Gambar 3 Pengaruh panjang serat terhadap kadar air papan partikel

\subsection{MOE ( Modulus of Elastycity )}

Pengujian kuat lentur papan partikel atau Modulus of Elasticity diuji dengan menggunakan Universal Testing Mechine (UTM) dengan jarak sangga $8 \mathrm{~cm}$ dengan memberikan beban yang tegak lurus terhadap permukaan sampel. Nuryawan dkk (2008) menyatakan bahwa kekuatan papan partikel bergantung terhadap homogenitas geometri papan partikel. Semakin homogen papan partikel maka akan semakin sedikit rongga udara yang terbentuk (Septriari dkk., 2014). Kuat lentur pada penelitian ini lebih tinggi dari penelitian yang telah dilakukan oleh Najihah (2018) dengan menggunakan panjang serat $3 \mathrm{~cm}$, artinya panjang serat pada penelitian ini sangat mempengaruhi nilai kuat lentur yang dihasilkan. Rednahnya nilai MOE pada penelitian ini disebabkan karena masih adanya pori-pori yang terdapat pada papan. Nilai MOE menurut SNI 03-2105-2006 mensyaratkan minimal sebesar $20.400 \mathrm{~kg} / \mathrm{cm}^{2}$. Hasil penelitian menunjukkan bahwa nilai kuat lentur papan partikel atau MOE tidak memenuhi standar SNI 03-2105-2006. Pengaruh panjang serat terhadap nilai MOE dapat dilihat pada Gambar 4.

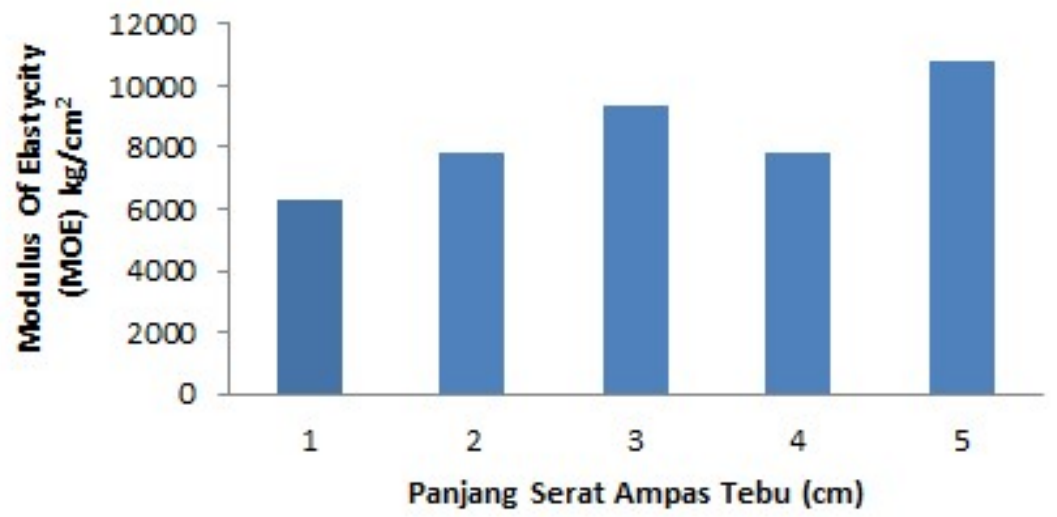

Gambar 4 Pengaruh panjang serat terhadap MOE papan partikel

\subsection{MOR ( Modulus of Rupture )}

Nilai kuat tekan papan partikel berbanding lurus dengan nilai kerapatan. Panjang serat ampas tebu juga berpengaruh pada kerapatan papan partikel, dimana papan partikel dengan panjang serat tebu $5 \mathrm{~cm}$ akan memiliki kerapatan yang baik dari papan partikel dengan panjang $1 \mathrm{~cm}$. Najihah (2018) telah melakukan penelitian dengan menggunakan bahan yang sama, mendapatkan nilai kuat patah tertinggi yaitu pada campuran massa serbuk kakao dan serat tebu yang sama (50:50) dan panjang serat tebu $3 \mathrm{~cm}$ dengan nilai sebesar $263,56482 \mathrm{~kg} / \mathrm{cm}^{2}$. Nilai kuat tekan yang didapatkan pada penelitian ini sangat tinggi yaitu $1,78 \times 10^{-4}-2,75 \times 10^{-4}$ $\mathrm{kg} / \mathrm{cm}^{2}$, disebabkan oleh komposisi antara matriks dan filler yang sama (50:50) dan pengaruh 
panjang serat tebu dengan variasi $1-5 \mathrm{~cm}$ yang digunakan. Nasution (2018) menyatakan bahwa dengan perbandingan antara matriks dan filler yang sama mengakibatkan kuatnya ikatan filler dengan matriks. Pengaruh panjang serat terhadap nilai MOR dapat dilihat pada Gambar 5.

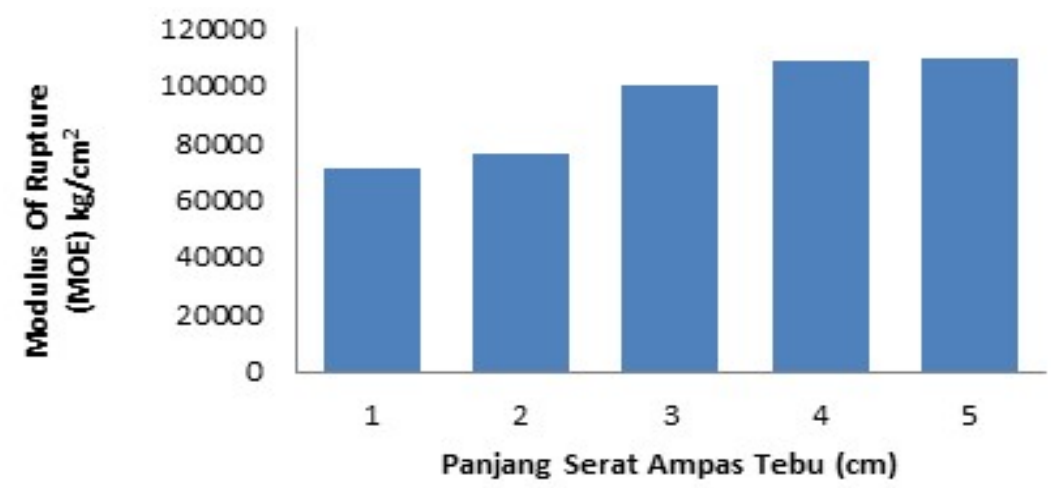

Gambar 5 Pengaruh panjang serat terhadap MOR papan partikel

\subsection{Konduktivitas Termal}

Pengujian sifat konduktivitas termal papan partikel dilakukan dengan metode plat dua rangkap dengan menggunakan ruang yang terisolasi, kemudian dilakukan pemberian suhu ruangan dengan bola lampu pijar 75 watt. Pada papan partikel dengan panjang serat $5 \mathrm{~cm}$ memiliki nilai kerapatan yang tinggi dibandingkan papan partikel dengan panjang serat $1 \mathrm{~cm}$. Faktor yang dapat mempengaruhi konduktivitas termal papan partikel yaitu kepadatan atau porositas. Apabila papan partikel dihasilkan memiliki banyak pori-pori maka konduktivitas termal papan tersebut akan semakin kecil. Bahan yang baik yang dijadikan sebagai bahan untuk isolator panas yang baik memiliki nilai konduktivitas termal sekitar $0,1 \mathrm{~W} / \mathrm{m}^{\circ} \mathrm{C}$ (Wibowo dkk, 2008). Pengaruh panjang serat terhadap nilai konduktivitas termal dapat dilihat pada Gambar 6.

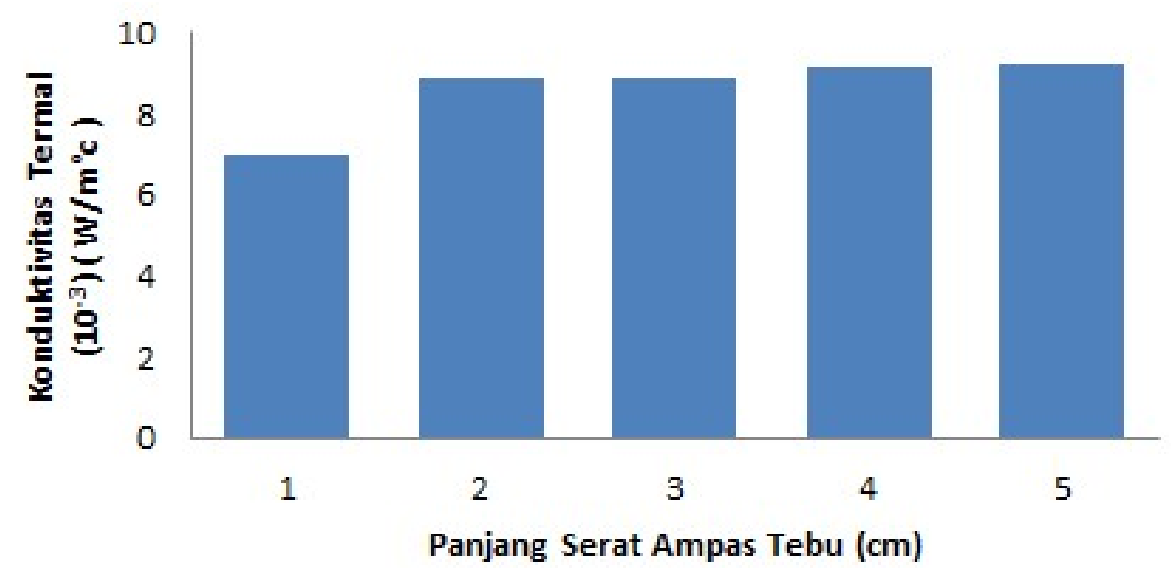

Gambar 6 Pengaruh panjang serat terhadap konduktivitas termal papan partikel

\section{KESIMPULAN}

Berdasarkan penelitian yang telah dilakukan dapat disimpulkan bahwa pengaruh panjang serat ampas tebu yang digunakan mempengaruhi kerapatan papan partikel yang dihasilkan. Papan partikel yang memiliki panjang serat $5 \mathrm{~cm}$ adalah papan yang memiliki kerapatan tinggi, dan papan yang memiliki panjang serat $1 \mathrm{~cm}$ adalah papan yang memiliki kerapatan yang rendah. Hasil penelitian menunjukkan bahwa papan partikel yang dihasilkan sudah memenuhi SNI 03-2105-2006, dan pengujian konduktivitas termal didapatkan hasil sesuai teori yaitu dibawah $0,1 \mathrm{~W} / \mathrm{m}^{\circ} \mathrm{C}$ namun pada pengujian mekanis uji kuat lentur nilai yang dihasilkan belum memenuhi standar dan nilai densitas papan yang didapatkan lebih tinggi dari standar. 


\section{DAFTAR PUSTAKA}

Ashadi, R.W., Pembuatan Gula Cair dari Pod Coklat dengan Menggunakan Asam Sulfat, Enzim, serta Kombinasi Keduanya, Skripsi, Fakultas Teknologi Pertanian, IPB, Bogor, 1988.

Krisna, M., Pemanfaatan Ampas Tebu Sebagai Bahan Baku Dalam Pembuatan Papan Partikel, Skripsi, Fakultas Pertanian Universitas Sumatera Utara, Medan, 2009.

Iswanto, A. H, Papan Partikel dari Ampas Tebu, Jurnal Ilmu dan Teknologi Kayu, 10, 103-111, 2009.

Maiwita, F., Darvina, Y., dan Yukifli, F., Pengaruh Komposisi Ampas tebu dan Serbuk Gergaji pada Papan Partikel terhadap Konduktivitas Termal, Jurnal Pillar Of Physics, 1, 41-48, 2014.

Malau, J.C., Sucipto T., dan Iswanto A.H., Kualitas Papan Partikel Batang Pisang Barangan Berdasarkan Variasi Kadar Perekat Phenol Formaldehida, Peronema Foresty Science Jurnal, 5, 32-38, 2015.

Maloney, TM., Modern Particleboard and Dry-Process Fiberboard Manufacturing, San Fransisco: Miller Freeman, 1997.

Muharam, A., Pengaruh Ukuran Partikel dan Kerapatan Lembaran terhadap Sifat Fisis dan Mekanis Papan Partikel Ampas Tebu, Skripsi, Fakultas Teknologi Pertanian, Institut Pertanian Bogor, Bogor, 1995.

Najihah, F, Y., Puryanti, D., dan Yetri, Y., Pengaruh Komposisi Kulit Buah Kakao, Ampas Tebu, dan Perekat terhadap Sifat Fisis dan Sifat Mekanis Papan Prtikel dari Campuran Limbah Kulit Buah Kakao dan Ampas Tebu, Jurnal Fisika Unand, 7, 1, 41-45.Brown, M. P. dan Austin, K., Appl. Phys. Letters 85, 2503-2504, 2018.

Nasution, M, Widi., Analisis Pengaruh Komposisi Partikel Ampas Tebu dan Partikel Tempurung Kelapaterhadap Sifat Fisisdan Mekanis Komposit Papan Partikel Perekat Resin Epoksi, Skripsi, Jurusan Fisika, Universitas Andalas, Padang, 2018.

Nuryawan, A., Massijaya, M.Y., dan Hadi, Sifat Fisis dan Mekanis Oriented Strand Board (OSB) dari Akasia Eukaliptus dan Gmelina Berdiameter Kecil serta Pengaruh Jenis Kayu dan Macam Aplikasi Perekat, Jurnal Ilmu dan Teknologi Hasil Hutan, 1, 2, 60-66, 2008.

Ruhendi, S., Koroh, F.A., dan Syamani, H., Analisa Perekat Kayu, Jurnal Kehutanan, Fakultas Kehutanan, Fakultas Kehutanan Insitut Pertanian Bogor, 18, 2007.

Septiari, P.W., Karyasa, W., dan Kartowarsono., Pembuatan Papan Partikel dari Limbah Plastik Polyprophylene (PP) dan Tangkai Bambu, Jurnal Kimia Visvitalis Universitas Pendidikan Ganesha, 2, 1, 117-126, 2004.

Wibowo, H., Rusianto, T., Ikhsan, M., Pengaruh Kepadatan dan Ketebalan Terhadap Sifat Isolator Panas Papan Partikel Sekam Padi, Jurnal Teknik Mesin Fakultas Teknik Institut Sains dan Teknologi AKPRIND, Yogyakarta, 106-111, 2008. 